\title{
Gerincferdülés esetén tapasztalt szagittális megjelenés vizsgálata EOS 2D/3D képalkotás használatával
}

\author{
DR. BURKUS MÁTÉ1,2 , JÓZSEF KRISTÓF¹, BÁLINT GERGELY', \\ DR. NIKLAI BÁLINT ${ }^{1}$, DR. MÁRKUS ISTVÁN ${ }^{1}$, DR. TUNYOGI-CSAPÓ MIKLÓS ${ }^{1}$
}

\section{ÖSSZEFOGLALÁS}

A gerincferdülés, a tér mindhárom síkját érintő összetett elváltozás, így értékelésekor, a frontális képen túl a szagittális megjelenés részletes megismerése is kiemelt jelentőséggel bír. Jelen közlemény célja, a serdülőkori, ismeretlen eredetű gerincferdülés szagittális megjelenésének nagy esetszámú, hazai populáción alapuló vizsgálata volt. 412 gerincferdüléssel rendelkező és 55 kontroll eset EOS 2D/3D képalkotását dolgoztuk fel. A 3D gerinc rekonstrukciókat követően kapott nyíl irányú paramétereket független mintás t-próbával és lineáris regresszióval hasonlítottuk össze. A szagittális paraméterek közül a háti kyphosis

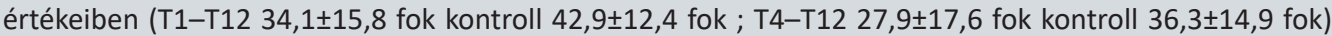
tapasztaltunk szignifikáns csökkenést ( $p<0,001)$. Az ágyéki gerinc, illetve a medenceparaméterek statisztikai eltérést nem mutattak. Az eredmények a Lenke klasszifikáció szerinti eltérő főcsoportok esetén azonosnak mutatkoztak. Különböző népcsoportoknál a medence szagittális megjelenése eltérő, illetve arra a gerincferdülés nem rendelkezik megjósolható hatással, az csupán a háti kyphosist befolyásolja lordotikus irányba. A szagittális megjelenésre a frontális görbületi képéből egyértelmű információt nem lehet levonni, így azt minden esetben egyedileg kell értékelni.

\section{Kulcsszavak: $\quad$ Gerincferdülés; Háromdimenziós képalkotás; Medence; Radiográfiai módszerek; Scoliosis; Serdülökor;}

M. Burkus, K. József, G. Bálint, B. Niklai, I. Márkus, M. Tunyogi-Csapó: Assessment of the sagittal morphology of scoliosis with EOS 2D/3D imaging

Scoliosis is a complex spinal deformity affecting all three planes, besides the evaluation of frontal appearance; the sagittal alignment also has high significance. The present study was aimed to evaluate the sagittal appearance of high number of adolescent idiopathic scoliosis cases in a Hungarian population. EOS 2D/3D images of 412 scoliotic and 55 control cases were involved. After the EOS 3D reconstructions were completed, the sagittal parameters were analysed with independent sample t-test and linear regression. In case of scoliosis only the thoracic kyphosis (T1-T12 $34,1 \pm 15,8^{\circ}$ control 42,9 $\pm 12,4^{\circ}$, and T4$\mathrm{T} 1227,9 \pm 17,6^{\circ}$ control $\left.36,3 \pm 14,9^{\circ}\right)$ showed significant decrease $(\mathrm{P}(0,001)$. The lumbar lordosis and the pelvic parameters did not have any significant difference. Very similar results were found in different Lenke subgroups. Different nations have various spino-pelvic appearances, which is not predictably affected by scoliosis. Adolescent idiopathic scoliosis has lordotic effect only on thoracic kyphosis. From coronal appearance of the curve no information can be concluded with regard to the sagittal view, so each case should be judged individually.

\section{Keywords:}

Adolescence; Imaging, three-dimensional - Methods; Pelvis - Radiography; Radiography - Methods; Scoliosis - Radiography; Spine - Radiography; 


\section{BEVEZETÉS}

A gerincferdülés, nem csupán, egy, a frontális síkban való elhajlás, hanem a tér mindhárom síkjára kiterjedő, összetett deformitás. Kialakulásának pontos megértéséhez, progreszsziójának előjelzéséhez, illetve kezelésének optimalizálásához szükséges a homlok síkú képen túl, a nyíl irányú megjelenés részletes ismerete is.

A medence, illetve a gerinc szagittális paramétereit számos szerző értékelte, mind betegségektől mentes „normál” (3, 25, 32), mind pedig gerincelváltozásokkal - többek között gerincferdüléssel rendelkező - populációk esetén $(6,20,31)$. Az irodalomban publikáltak szerint, az eltérő népcsoportok vizsgálata során, „,normál” csoportok összehasonlításakor is különböző szagittális megjelenés volt észlelhető, amelyek hátterében a populációk egyéni különbségeit valószínűsítik.

A medence és a gerinc között fennálló dinamikus kapcsolatrendszer jól meghatározott, amely a fejtől egészen az alsó végtagokig tart, alapkövét pedig maga a medence adja. A rendszerben bekövetkező változás, érintse az egység bármely elemét, hatással van a többire is (2). Magát a medence morfológiát és annak térbeli helyzetét Legaye és Duval-Beaupère által meghatározott medenceparaméterekkel lehet a legjobban jellemezni. Közülük kiemelendő a medence incidencia (Pelvic Incidence, PI), ami a szagittális síkban a keresztcsonti plató középpontjára állított merőleges, és a szintén ebből a pontból indított, a combfej centrumokat összekötő egyenes középpontjához vezető szakasz által bezárt szöget jelenti. A PI szögértékét, egy egyénre jellemző anatómiai állandóként adják meg, amely független a térbeli helyzettől, így a szagittális megjelenés specifikus kulcsfaktorának tekintendő $(8,15)$. A medence és a gerinc szoros kapcsolatának köszönhetően, a medence incidencia értékének növekedésével, a keresztcsont állása az acetabulumok helyzetéhez viszonyítva megváltozik. A keresztcsont platója ventral és caudal felé billen, míg a teste horizontálisabb helyzetűvé válik. Az így kialakult állapotot ellensúlyozva pedig kifejezettebb gerincgörbületek jelennek meg, elsősorban az ágyéki szakaszon. Kisebb PI értékhez a sacrum testének függőlegesebb helyzete, valamint a zárólemez vízszintesebb állása, következésképp kisebb görbületek, így relatív egyenesebb gerinc társul. Ez az állapot kisebb adaptációs lehetőséget biztosít a gerinc számára, ami csökkenti annak kompenzációs lehetőségeit a megfelelő szagittális egyensúly helyreállításában (15).

Ismert, hogy a szagittális megjelenés különbözik bizonyos medence-gerinc egységet érintő betegségek, deformitások esetén, illetve jelentősen megváltozik a növekedési során is. A spino-pelvicus egységre jellemző paraméterek bizonyítottan alakulnak a gyermekkor előre haladtával a pubertáson át, egészen a felnőtt állapot eléréséig $(19,21,30)$. Továbbá, a megfigyelések szerint egy „normál” kontrollcsoporthoz viszonyítva a szagittális paraméterek különböznek olyan állapotok esetén is, mint gerincferdülés, spondylolisthesis vagy ágyéki porckorong rendellenességek $(1,14,25)$, valamint közvetetten a derékpanaszokkal is összefüggést mutathatnak (10).

A medenceparaméterek megváltozása esetén annak következményes hatása, leginkább a hozzá legközelebb álló gerincszakaszon, tehát az ágyéki lordosisnál jelenik meg, de emellett, bizonyos mértékben, a távolabbi szakaszokra, így a háti kyphosisra is kihatással lehet $(8,15)$. Ezt a megfigyelést támasztja alá Clément és munkatársai vizsgálata is. Ők az ágyéki görbületet is két külön részből állóként kezelték. Megfigyeléseik szerint, a lumbalis lordosis cranialis része a háti kyphosis mértékétől függ, míg annak caudalis vége már magától a medence helyzetével, tehát a medence incidenciával hozható kapcsolatba (5).

A scoliosis, mint többsíkú deformitás, a gerinc frontális megjelenését jellegzetes módon változtatja meg. Ezzel ellentétben a szagittális kép, illetve annak a frontális görbülettel való kapcsolata már korántsem ennyire világos. Gerincferdüléssel rendelkező esetek vizsgálata során egyes szerzők a medence incidencia és az ágyéki gerincgörbület - lordosis - közötti kapcsolatot a normál populációnál észleltekkel közel megegyezőnek találták, továbbá a háti kyphosis mértékével is igazoltak összefüggést $(13,15)$. Ezzel ellentétben, más publikációk szerint nincs statisztikai kapcsolatot a háti kyphosis, valamint az ágyéki lordosis alakulása között, gerincferdülés esetén (18).

A gerincdeformitások - különösképp a gerincferdülés - vizsgálatában nagy előrelépést jelentett egy olyan diagnosztikai eljárás 
megjelenése, amely az összetett deformitásokat ténylegesen háromdimenzióban képes értékelni alacsony sugárterhelés mellett. Ilyen eszköz a jelen vizsgálat során alkalmazott EOS 2D/3D teljes test szkenner, amely Georges Charpak Nobel-díjas röntgendetektálási elvén alapuló diagnosztikus készülék (4). A berendezés, illetve a hozzá kapcsolt rekonstrukciós szoftvercsomag forradalmi eredményt hozott mind a gerinc $(11,12)$, mind az alsó végtagok $(27,28)$ vizualizációs lehetőségeiben. Az általa biztosított felszíni, háromdimenziós megjelenítés olyan új klinikai paraméterek meghatározását tette lehetóvé, amelyek a konvencionális 2D ábrázolás használata mellett korábban nem voltak meghatározhatók (7). Az eszköz alkalmazhatóságát a medence-gerinc egység megjelenésével kapcsolatban, valamint az alsó végtagok tekintetében, több klinikánkon végzett korábbi vizsgálat is bizonyította $(11,12$, 26-28, 30).

Minél részletesebb ismeretekkel rendelkezünk a gerincferdülés mellett tapasztalt szagittális megjelenésről, annál pontosabb következtetéseket vonhatunk le az elváltozások kialakulásával és progressziójával kapcsolatban, elősegítve ezzel a betegség megelőzését, illetve megfelelő kezelését.

Jelen vizsgálat célja volt, hogy a spinopelvicus egység szagittális megjelenését, nagy esetszámú, fiatalkori, ismeretlen eredetú gerincferdüléssel rendelkező hazai populáción értékelje, pontos, alacsony sugárterhelésú röntgenképalkotás használatával.

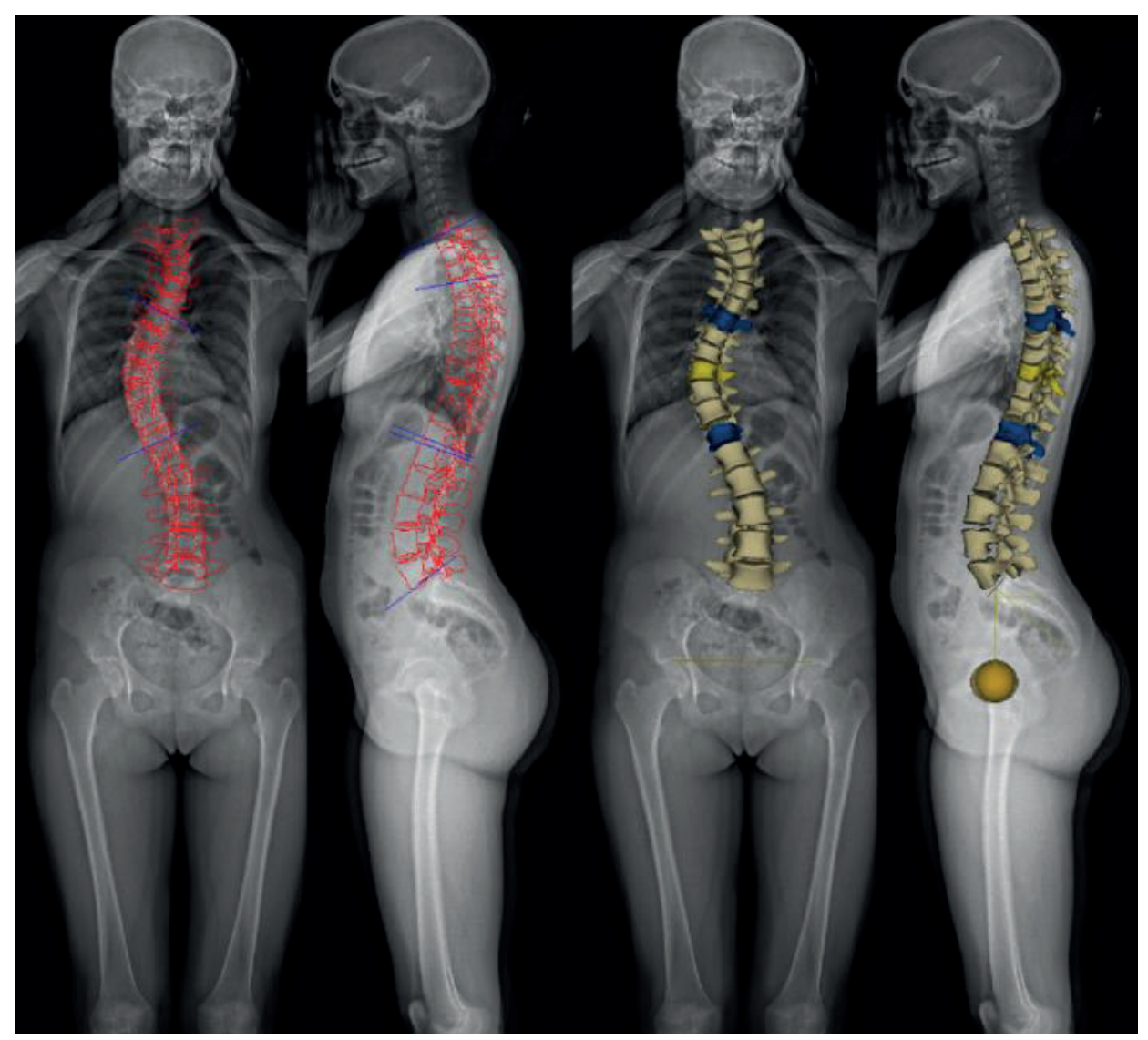

1. ábra EOS felvétel

17 éves lány T6-T9-T12 csigolyák között fennálló jobbra konvex háti görbületének, rekonstrukciója. A Cobb-szög értéke 38 fok, Lenke beosztás szerint: 1BN. 


\section{ANYAG ÉS MÓDSZER}

A vizsgálat során klinikánk radiológiai adatbázisát tekintettük át a 2007 és 2012 közötti időszakra vonatkozóan, visszamenően. 491 (94 férfi 397 nő) 15 fokot meghaladó Cobb-szögértékű eset EOS 2D/3D felvételét értékeltük. Kizártunk minden ismert okból kialakult gerincelváltozást, valamint azokat, ahol korábban bármilyen, a gerincet és az alsó végtagokat érintő sebészeti beavatkozás történt.

$\mathrm{Az}$ eseteket a gerincferdülés beosztásban 2001 óta alkalmazott, jelenleg leginkább elfogadott, Lenke szerinti klasszifikációs rendszert használva kategorizáltuk. Ez egy kétdimenziós röntgenalapú beosztás, alapját a görbület frontális síkban való megjelenése adja, de az alcsoportok meghatározása során már a szagittális megjelenést („sagittal modifier”) is számba veszi (16).

A vizsgálat során a Lenke szerinti beosztás három leggyakoribb főcsoportjával foglalkoztunk, így összesen 412 (75 férfi 337 nő) fiatalkori ismeretlen eredetű gerincferdüléssel rendelkező esetet tudtunk bevonni, átlagéletkor: 16,9₫4,6 év. A klasszifikációt követően az esetek megoszlása; Lenke 1 csoport (L1, háti görbület): 165 fő (34 fiú, 131 lány); Lenke 3 csoport (L3, kettős görbület): 92 fő (12 fiú, 80 lány); Lenke 5 csoport ( $L 5$, háti-ágyéki vagy ágyéki görbület): 155 fő (29 fiú, 126 lány). A klasszifikáció szerint részletes megoszlást az $I$. táblázatban, míg a görbülete mértékének átlagát a Il. táblázatban foglaltuk össze.

Kontrollként egy gerincbetegségektől mentes 55 főből álló csoportot (23 fiú, 32 lány) használtunk. Itt a képalkotás indikációja részben gerincferdülés gyanúja volt, amelyet a vizsgálat nem igazolt. A csoport másik részénél ismeretlen eredetű ízületi fájdalom miatt készült a felvétel, amely hátterében végül csont érintettséget nem találtunk. A kontrollcsoport átlagéletkora 17,1 $\pm 4,1$ év volt.

A képalkotásokhoz az intézetünkben 2007 óta klinikai használatban lévő, EOS 2D/3D (EOS Imaging, Párizs, Franciaország) készüléket használtuk. Az eszköz kiváló minőségű, szimultán keletkező, terhelt (álló) testhelyzeti, anteroposzterior és laterális, teljes test leképezést biztosít, alacsony sugárdózis mellett (1. ábra).

A felvételek kivétel nélkül ortopédiai indikációval, ambuláns betegellátás során készültek.
A képalkotó vizsgálat előtt a páciensek, illetve a szülők írásos beleegyezésben járultak hozzá a vizsgálathoz, illetve az adatok később kutatási célra való felhasználhatóságához.

A képanyag értékelése a sterEOS (v1.3.4.3740, EOS Imaging, Párizs, Franciaország) programcsomaggal történt. A háromdimenziós rekonstrukciókat a program használatában nagy gyakorlattal rendelkező, annak kezelésében speciális képzést szerzett $\mathrm{PhD}$ hallgató végezte. A vizsgáló munkájának megbízhatósági értékelésére úgy került sor, hogy 25 véletlenszerúen kiválasztott esetet három független alkalommal értékelt. A kapott eredményeket csoporton belüli korrelációs vizsgálattal értékeltük a Winer kritériumok alapján: 0-0,24 csoporton belüli korrelációs koefficiens esetén gyenge (vagy hiányzó), 0,25-0,49 esetén alacsony, 0,50-0,69 között közepes, 0,70-0,89 esetén jó, 0,90 felett kiváló megbízhatóságot állapítható meg (33).

A program által automatikusan generált, és vizsgálatunkban felhasznált paraméterek (2-3. ábra):

- Cobb- szög (a gerincferdülés végcsigolyáinak a görbület csúcsától távolabb eső zárólemezén átfektetett egyenesekre állított merőlegesek által bezárt szög kiegészítő szöge);

- T1-T12 és T4-T12 kyphosis, (A kyphosis és a lordosis értékek a cranialis csigolya felső zárólemeze és a caudalis csigolya alsó zárólemeze által bezárt szögértéket jelentik);

- L1-L5 lordosis (meghatározást lásd fent.);

- Medencedőlés (Pelvic Version, PV, a combfejeket összekötő vonal középpontját a keresztcsont plató középpontjához kötő szakasznak a függőlegessel bezárt szöge);

- Keresztcsonti lejtés (Sacral Slope, SS, a keresztcsonti plató síkjának a vízszintessel bezárt szöge);

\section{- Medence incidencia}

A Lenke klasszifikáció szerinti beosztást minden esetnél manuálisan végeztük el a program 2D munkaállomásán. Itt értékeltük a klasszifikációs kritériumok között szereplő keresztcsonti középvonal (CSVL - central sacral vertical line - az elölnézeti képen a keresztcsont zárólemezének középpontjába állított függőleges vonal) helyzetét, melynek az ágyéki 
görbület csúcs csigolyájához viszonyított lefutása alapján lehet elkészíteni a Lenke beosztás ágyéki „L mod." alcsoportját, majd a szagittális modifier "S mod." szerinti csoportosítás is megtörtént. Ez a T5-T12 kyphosis képe alapján kategorizál (10 fok alatt „negatív”; 10-40 fok között „normál”; 40 fok felett „pozitív”).

A paraméterek értékeinek statisztikai feldolgozása az SPSS v22 (IBM Corp., Armonk, NY, USA) és Microsoft Office Professional Plus v14.0.6112.5000 (Microsoft Corp., Redmond,
WA, USA) programcsomagok használatával történt. Statisztikai elemzés során, az értékek eloszlását a Kolmogorov-Smirnov teszttel vizsgáltuk. A kontroll- és a scoliotikus csoport, valamint az egyes alcsoportok közötti összefüggések megítélése független mintás t-próbával, míg a paraméterek kapcsolatának vizsgálata, lineáris regresszió analízissel történt. A vizsgálatok során a $\mathrm{p}<0,05$ értéket tekintettük szignifikánsnak.

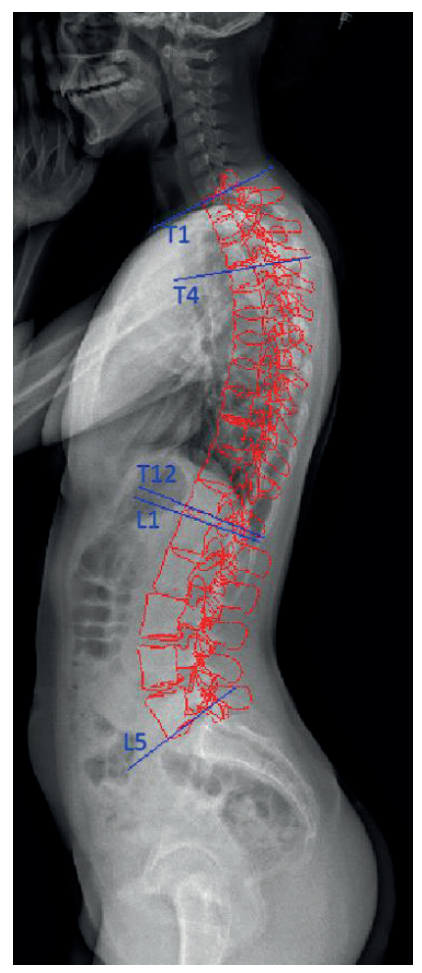

2. ábra Szagittális gerincparaméterek

Gerinc rekonstrukciót követő szagittális kontúrt ábrázoló megjelenítés; T1-T12, T4-T12 kyphosis és L1-L5 lordosis
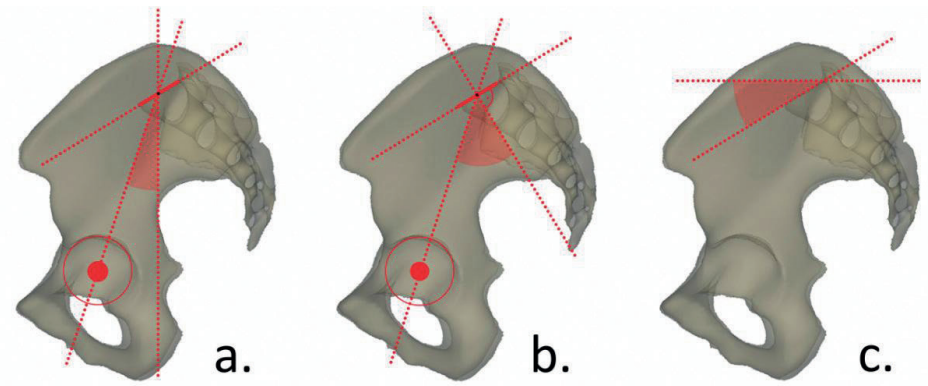

3. ábra Szagittális medenceparaméterek.

a.: Medencedőlés (Pelvic Tilt, PT vagy Pelvic Version, PV)

b.: Medence incidencia (Pelvic Incidence, $P I)$

c.: Keresztcsonti lejtés, (Sacral Slope, SS)

A paraméterek kapcsolata meghatározott $P I=P V+S S$ 
I. táblázat A vizsgált esetek Lenke klasszifikáció szerinti megoszlása

\begin{tabular}{|c|c|c|c|c|c|c|}
\hline & \multicolumn{3}{|c|}{ Lumbal modifier } & \multicolumn{3}{|c|}{ Sagittal modifier } \\
\hline & A & B & C & - & $\mathbf{N}$ & + \\
\hline $\begin{array}{l}\text { Lenke } 1 \\
(n=165)\end{array}$ & 131 & 28 & 6 & 34 & 108 & 23 \\
\hline $\begin{array}{l}\text { Lenke } 3 \\
(n=92)\end{array}$ & 5 & 30 & 57 & 30 & 55 & 7 \\
\hline $\begin{array}{l}\text { Lenke } 5 \\
(n=155)\end{array}$ & - & - & 155 & 9 & 127 & 19 \\
\hline $\begin{array}{l}\text { Összesen } \\
(n=412)\end{array}$ & 136 & 58 & 218 & 73 & 290 & 49 \\
\hline
\end{tabular}

II. táblázat Az egyes Lenke szerinti föcsoportok esetén tapasztalt görbületek átlag Cobb-szögértéke

\begin{tabular}{|c|c|c|}
\hline & Háti görbület & Ágyéki görbület \\
\hline & \multicolumn{1}{|c|}{ Cobb-szög átlag \pm S.D. (fok) } \\
\hline Lenke $\mathbf{1}(\mathbf{n = 1 6 5 )}$ & $36,6 \pm 20,4$ & - \\
\hline Lenke $\mathbf{3}(\mathbf{n = 9 2 )}$ & $57,9 \pm 22,9$ & $40,9 \pm 15,2$ \\
\hline Lenke $\mathbf{5}(\mathbf{n = 1 5 5 )}$ & - & $26,7 \pm 13,1$ \\
\hline Összes eset & $44,3 \pm 21,6$ & $32,1 \pm 15,5$ \\
\hline
\end{tabular}

\section{EREDMÉNYEK}

A megbízhatóság értékelése során a vizsgálati eredmények minden esetben 0,90 feletti csoporton belüli korrelációs koefficienst adtak, így kitűnőnek bizonyultak. Az összehasonlítás során minden paraméter eloszlása normálisnak mutatkozott a Kolmogorov-Smirnov teszt szerint.

Az eredményekként kapott fő szagittális medence- és gerincparaméterek átlagát, illetve standard deviációját a III. táblázatban foglaltuk össze, a kontroll- és a teljes gerincferdüléses csoportnál. Szignifikáns különbség $(p<0,001)$ a T1-T12 (kontroll 42,9 $\pm 12,4$ fok scoliosis $34,1 \pm 15,8$ fok), és T4-T12, (kontroll: $36,3 \pm 14,9$ fok scoliosis $27,9 \pm 17,6$ fok) háti kyphosis értékei között volt kimutatható, így egyértelmúen laposabb hát igazolódott. Az ágyéki gerinc és medenceparaméterek különbségénél szignifikáns eltérés egyik esetben sem mutatkozott $(p=0,524-0,811)$.

A Lenke klasszifikáción alapuló csoportosítás szerinti eredményeket, illetve azoknak a kontroll csoporthoz viszonyított statisztikai kapcsolatát a IV. táblázat ábrázolja. A scoliosis minden csoport esetén egyértelmúen hasonló lordotikus befolyással rendelkezik a T1-T12, és T4-T12 kyphosisra $(\mathrm{p}<0,001)$ (T1-T12: kontroll 42,9 $\pm 12,4$ fok; Lenke $134,1 \pm 17,5$ fok; Lenke 3 28,2 $\pm 18,1$ fok Lenke $538,8 \pm 14,4$ fok; T4-T12 kyphosis: Kontroll $36,3 \pm 14,9$ fok; Lenke $127,1 \pm 20,9$ fok Lenke 3 20,4 $\pm 19,1$ fok Lenke $532,6 \pm 13,8$ fok). Az ágyéki gerinc, valamint a medenceparaméterek a Lenke klasszifikáció szerinti felosztás egyik csoportjánál sem különböznek statisztikailag szignifikánsan a kontrollcsoporttól.

Lineáris regresszió analízis során kapott eredményeinkben a lumbalis lordosis értékei megegyező módon szignifikánsan korreláltak a keresztcsonti lejtéssel és a medence incidenciával (kontroll PI $p=0,024 \mathrm{~B}-0.29$; AIS p 0,001 B -0.49 , SS kontroll pr0,001 B 0,65 AIS p 0,001 B 0,59$)$. A háti kyphosis a kontrollcsoportnál a medencedőléssel $(p=0,016 \mathrm{~B}-0.34)$ míg a scoliotikus csoportnál a medencedóléssel ( $p<0,001$ B -0.25) és a medence incidenciával (p<0.001 B -0,24) is összefüggést mutatott. A különböző súlyossági csoportokat külön vizsgálva nem találtunk különbséget, a kapott eredmények hasonlónak bizonyultak. 
III. táblázat A kontroll- és gerincferdüléssel rendelkező vizsgálati csoportok esetén tapasztalt szagittális paraméterek és a két csoport statisztikai kapcsolata.

S.D. $=$ standard deviatio, $P I=$ medence incidencia,$P V=$ medencedőlés, $S S=$ keresztcsonti lejtés

\begin{tabular}{|c|c|c|c|}
\hline & Kontroll $(\mathbf{n = 5 5 )}$ & $\begin{array}{c}\text { Gerincferdülés } \\
(\mathbf{n}=\mathbf{4 1 2})\end{array}$ & \\
\hline & átlag \pm S.D. (fok) & átlag \pm S.D. (fok) & t-próba \\
\hline T1-T12 Kyphosis & $42,9 \pm 12,4$ & $34,1 \pm 15,8$ & p 0,001 \\
\hline T4-T12 Kyphosis & $36,3 \pm 14,9$ & $27,9 \pm 17,6$ & $\mathbf{p}<0,001$ \\
\hline L1-L5 Lordosis & $44,3 \pm 9,3$ & $46,1 \pm 13,2$ & $\mathrm{p}=0,811$ \\
\hline PV & $7,2 \pm 7,3$ & $7,6 \pm 8,4$ & $\mathrm{p}=0,719$ \\
\hline PI & $45,9 \pm 8,1$ & $46,9 \pm 12,2$ & $\mathrm{p}=0,524$ \\
\hline SS & $39,4 \pm 6,9$ & $39,0 \pm 10,2$ & $\mathrm{P}=0,723$ \\
\hline
\end{tabular}

IV. táblázat A Lenke szerinti klasszifikáció föcsoportjai esetén tapasztalt szagittális paraméterek, valamint a kontrollcsoporttal való statisztikai kapcsolatuk.

Kyp = kyphosis; Lord $=$ lordosis

\begin{tabular}{|c|c|c|c|c|c|c|c|}
\hline & (fok) & $\begin{array}{c}\text { T1-Т12 } \\
\text { Кур. }\end{array}$ & $\begin{array}{c}\text { T4-Т12 } \\
\text { Кур. }\end{array}$ & L1-L5 Lord. & PV & PI & SS \\
\hline Lenke 1 & $\begin{array}{l}\text { Átlag } \pm \text { S.D. } \\
\quad \text { (fok) }\end{array}$ & $34,1 \pm 17,5$ & $27,1 \pm 20,9$ & $46,8 \pm 13,9$ & $7,4 \pm 8,0$ & $46,4 \pm 11,8$ & $38,9 \pm 9,8$ \\
\hline K - L1 & t-próba & p 0,001 & p 0,001 & $p=0,668$ & $p=0,804$ & $p=0,914$ & $p=0,928$ \\
\hline Lenke 3 & $\begin{array}{l}\text { Átlag } \pm \text { S.D. } \\
\text { (fok) }\end{array}$ & $28,2 \pm 18,1$ & $20,4 \pm 19,1$ & $44,6 \pm 13,2$ & $8,6 \pm 9,8$ & $49,8 \pm 14,3$ & $41,1 \pm 10,3$ \\
\hline K - L3 & t-próba & $p<0,001$ & p 0,001 & $p=0,447$ & $p=0,321$ & $p=0,093$ & $p=0,195$ \\
\hline Lenke 5 & $\begin{array}{l}\text { Átlag } \pm \text { S.D. } \\
\quad \text { (fok) }\end{array}$ & $38,8 \pm 14,4$ & $32,6 \pm 13,8$ & $47,1 \pm 12,1$ & $7,3 \pm 8,1$ & $46,6 \pm 13,1$ & $38,9 \pm 11,4$ \\
\hline $\mathrm{K}-\mathrm{L5}$ & t-próba & $p=0,028$ & $p=0,021$ & $p=0,547$ & $p=0,876$ & $p=0,814$ & $p=0,894$ \\
\hline
\end{tabular}

\section{MEGBESZÉLÉS}

A serdülőkori ismeretlen eredetű gerincferdülés gyakori elváltozás, amely akár a populáció $1-2 \%$-át is érintheti. A deformitás, elsődleges problémát a frontális síkban okoz, de a teljes gerincre kihat a tér minden irányát érintve ezzel. A betegség időben történő felismeréséhez, progressziójának megítéléséhez, megelőzéséhez, illetve megfelelő kezeléséhez elengedhetetlen a térbeli megjelenésének részletes ismerete. Jelen vizsgálat során a szerzők nagy hazai esetszámon végzett öszszehasonlítás során értékelik az ismeretlen eredettel kialakult serdülőkori gerincferdülés szagittális síkú megjelenését.

A medence oldalnézeti képe, a növekedés során észlelt változásokon túl, bizonyítottan különbözik a medence-gerinc egységet érintő bizonyos deformitások esetén. Spondylolisthesises csoportnál a vizsgálatok a medence incidencia, valamint a keresztcsonti lejtés és ágyéki lordosis tekintetében is szignifikánsan emelkedett értékeket igazoltak, míg a háti kyphosis csökkentnek bizonyult $(1,14)$. Porckorong károsodással járó eseteknél a megfigyelések a PI-t a normálishoz nagyon hasonlónak, illetve enyhén csökkentnek találták, amelyhez következményesen csökkent lordosis, így kisebb gerincgörbületek, „laposabb" gerinc társult $(1,25)$.

Jelen vizsgálat eredményei nem találtak statisztikai különbséget a gerincferdüléssel rendelkező és a kontrollcsoport összehasonlítása során az oldalnézeti medenceparaméterek tekintetében, sem a teljes scoliotikus csoportra 
vonatkoztatva, sem a görbületi altípusokra való lebontást követően, hasonlóan Legaye és munkatársai által tapasztaltakhoz (15). Ezzel ellentétben más szerzők szerint a medenceparaméterek gerincferdülés esetén eltérést mutatnak a normál populációhoz viszonyítva. Upasani és munkatársai, valamint MacThiong és munkatársai scoliosisnál a medence incidencia értékeit szignifikánsan magasabbnak találták $(20,31)$. Valószínűsítették, hogy az emelkedett értékek egy kompenzatórikus hatás eredményei, mely segítségével a szervezet növelni próbálja az ágyéki görbületeket, hogy így stabilizálja a test globális egyensúlyát, különösen thoracalis görbület esetén. Felvetették, hogy a medence helyzetének megváltozása, az emelkedett PI értékek, esetleg rizikó faktorként szerepelhetnek a scoliosis kialakulásában (31). Stagnara és munkatársai feltételezik, hogy a medence incidencia értékeinek nem lehet nagy meghatározó szerepük a görbületek kialakításában, ami összefüggést mutat jelen közlemény eredményeivel (29).

Jelen vizsgálat alapját alkotó középeurópai - 55 esetből álló „normál” és nagy esetszámú (412) - ismeretlen eredetű gerincferdüléssel rendelkező populációk, vizsgálat során tapasztalt medence incidencia értékek megközelítik Mac-Thiong és munkatársai egészséges kaukázusi fiatalokon végzett összehasonlításnál tapasztaltakat $(49,1 \pm 11,0$ fok). Jelentősen alacsonyabbak azonban a Roussouly és munkatársai 160 „normál”, szintén kaukázusi eseteken végzett tanulmányában észlelteknél (51,91 $\pm 10,7$ fok), illetve Mac-Thiong másik, 160 gerincferdüléses eset értékelése során kapott $\left(57,3 \pm 13,8^{\circ}\right)$ értékeknél $(19,20,25)$. Hu és munkatársai 184 kínai gerincferdüléssel rendelkező eseten végzett vizsgálatukban tapasztalt PI eredmények (43,1 $\pm 10,1$ fok) viszont jelentősen alacsonyabbak, mint jelen vizsgálat során észleltek (9).

A különböző populációk szagittális medenceparaméter értékeiben tehát jelentős különbségek mutatkoznak, mind a gerinc érintettség nélküli „normál” csoportnál, mind pedig gerincferdülés mellett. A tapasztalt különbségek pedig nagyobbrészt a populációs eltérésekből adódó variációk, mint a gerincelváltozásoknak a medencére kifejtett hatásának következményei. Ezt támasztja alá Lonner és munkatársai tanulmánya is, akik 115 afro-amerikai és 421 fehér bőrű amerikai gerincferdüléssel rendelkező páciensen végzett összehasonlításukban a medence incidencia, a medencedőlés és az ágyéki lordosis tekintetében is szignifikánsan emelkedett eredményeket észleltek a színes bőrű populációnál (18).

Jelen tanulmány eredményei szerint az ágyéki gerinc nyíl irányú paraméterei, a kontroll populációtól statisztikailag nem térnek el, függetlenül a deformitások frontális síkú megjelenésétől. A kapott értékek pedig összevágnak az irodalomban más szerzők által tapasztaltakkal. A háti kyphosis mértékét tekintve, viszont egyértelmúen szignifikáns változás - csökkenés - mutatkozott minden csoportnál a T1-T12 és T4-T12 kyphosis tekintetében. A tapasztaltak egyezést mutatnak Upasani és munkatársai háti és ágyéki görbületeken (Lenke 1 és Lenke 5) végzett összehasonlításában találtakkal, ahol a két görbület típus között szintén nem volt statisztikailag kimutatható különbség (31), valamint egyeznek $\mathrm{Hu}$, illetve $\mathrm{Li}$ és munkatársai által észleltekkel is $(9,17)$. Eredményeink ellentmondanak viszont Mac-Thiong és munkatársai tapasztalatainak, akik szerint az ágyéki görbülettel rendelkező gerincferdülés esetén a kyphosis szignifikánsan, míg a lordosis nem szignifikánsan, de magasabb értéket mutat, mint a háti görbülettel rendelkezőknél (20).

A medence nyíl irányú paraméterei és a gerinc görbületi megjelenése közötti összefüggéseket először Stagnara és munkatársai demonstrálták. Vizsgálatuk szerint szoros kapcsolat figyelhető meg az ágyéki görbület és a keresztcsonti lejtés között (29). A keresztcsont helyzete és az ágyéki görbület erős kapcsolatát saját eredményeink is megerősítik, mind a scoliotikus, mind a kontrollcsoport esetén, más szerzők eredményeivel megegyező módon $(13,15,17)$.

A különböző frontális görbületek esetén az irodalomban észlelt szagittális megjelenés tehát nem teljesen egységes. Jelen vizsgálat eredményei egybevágnak $\mathrm{Hu}$ és munkatársai által tapasztaltakkal, miszerint gerincferdülés esetén a frontális megjelenés és a szagittális kép kapcsolta limitált, egyikből a másikra vonatkozó egyértelmű következtetést levonni nem lehet (9).

A gerincferdülés kezelése során, mind a konzervatív, mind az operatív módszerek alkalmazásakor, illetve azok tervezésekor is, 
hangsúlyt kell fordítani a szagittális megjelenés megfelelő értékelésére, valamint beállítására is. A manapság rutinszerűen alkalmazott deformitás klasszifikáció (Lenke) úgy tűnik a szagittális megjelenés vonatkozásában nem ad megfelelő támpontot a mútéti korrekciók tervezéséhez, ezért a közelmúltban több szerző is foglalkozott a szagittális megjelenés új osztályozásával (25). A mútéti korrekció során törekedni kell a frontális korrekciót kiegészítve a görbület nyíl irányú egyensúlyának megtartására, illetve helyreállítására is, lehetőleg harmonikus szagittális profil kialakításával. A korrekció során a nyíl irányú egyensúly helyreállításban ejtett hiba elősegíti a degeneratív károsodások korai megjelenését, melyek a mútéteket követően leginkább a szomszédos, fúzió nélküli szakaszon lévő mozgó szegmentumokban alakulhatnak ki, úgynevezett szomszédos szegmentum szindróma formájában. Ez tüneteket okozóan leginkább a caudalis szomszédos szegmentumokat érinti, kialakulásában a még mozgó szegmentumok túlterhelését okolhatjuk, amely a kisízületek és a discusok korai degenerációját eredményezheti. A cranialis szomszédos szegmentumoknál jelentkező proximalis junkcionális kyphosis (PJK) is a rosszul beállított szagittális balansz következménye, deformitás korrekciókat követően prevalenciája hozzávetőlegesen 20\%-os gyakorisággal alakulhat ki, többségében tünetmentesen (22). Okaként különböző szerzők a rigid transpedicularis csavaros rögzítést, valamint a szagittális hypokyphosist jelölik meg. Deformitás korrekciók során gyakori az úgynevezett "flatback" szindróma kialakulása is (24), amely szintén a szomszédos szegmentumok túlterhelését okozhatja.

Jelen nagy esetszámnál, pontos módszerrel végzett vizsgálat Magyarországon egyedülállóan, illetve nemzetközi viszonylatban is jól mutatja az ismeretlen eredetű serdülőkori gerincferdülés szagittális spino-pelvicus megjelenését, illetve más szerzők által tapasztaltakhoz viszonyított különbségeit, továbbá az eredmények hazai referencia értékeknek is tekinthetők.

Vizsgálatunk eredményeit limitálja a kontrollként használt csoport relatív alacsony esetszáma, a nemi arányok különbözősége, valamint, a ritkább, Lenke szerinti csoportosítás L2 (dupla háti görbület), L4 (tripla görbület), és L6 (háti-ágyéki átmenti vagy tisztán ágyéki fő görbület hozzá tartozó háti komponenssel) csoport hiánya.

Vizsgálatunk konklúziójaként elmondható, hogy a medence-gerinc egység szagittális irányú megjelenése nem egységes. Mind gerincbetegségektől mentes eseteknél, mind pedig gerincferdülés esetén jelentős eltérések mutathatók ki a különböző népcsoportok között, amelyek hátterében populációs különbségek állhatnak. Az ismeretlen eredetű serdülőkori gerincferdülés egyértelmű lordotikus jellegú elváltozást eredményez, melynek statisztikailag alátámasztott hatása csak a háti kyphosisra van. A deformitásnál a szagittális képre vonatkozó egyértelmű következtetést a frontális görbületi megjelenésből nem lehet levonni, így azt minden esetben egyedileg, függetlenül kell értékelni.

\section{Köszönetnyilvánítás:}

A jelen tudományos közleményt a szerzők a Pécsi Tudományegyetem alapításának 650. évfordulója emlékének szentelik.

A tanulmány megvalósulását a GINOP-2.3.2-15-2016-00022, 3D nyomtatási és vizualizációs technológiákat alkalmazó interdiszciplináris kutatási, oktatási és fejlesztési központ kialakítása a Pécsi Tudományegyetemen projekt támogatta. 


\section{IRODALOM}

1. Barrey C., Jund J., Noseda O., Roussouly H., Dubois J., Miron M.C., et al.: Diagnostic imaging of spinal deformities: reducing patients P.: Sagittal balance of the pelvis-spine complex and lumbar degenerative diseases. A comparative study about 85 cases. Eur. Spine J. 2007. 16. (9): 1459-1467. https://doi.org/10.1007/s00586-006-0294-6

2. Berthonnaud E., Dimnet J., Roussouly P., Labelle H.: Analysis of the sagittal balance of the spine and pelvis using shape and orientation parameters. J. Spinal Disord. Tech. 2005. 18. (1):40-47. https://doi.org/10.1097/01.bsd.0000117542.88865.77

3. Boulay C., Tardieu C., Hecquet J., Benaim C., Mouilleseaux B., Marty C., Prat-Pradal D., Legaye J., Duval-Beaupère G., Pélissier J.: Sagittal alignment of spine and pelvis regulated by pelvic incidence: standard values and prediction of lordosis. Eur. Spine J. 2006. 15. (4): 415-422. https://doi.org/10.1007/s00586-005-0984-5

4. Charpak G..: Les perspectives ouvertes, pour la medecine, par les nouveaux detecteurs de rayonnements ionisants. Bull. Acad. Natl. Med. 1996. 180. (1): 161-168.

5. Clément J. L., Geoffray A., Yagoubi F., Chau E., Solla F., Oborocianu I., Rampal V.: Relationship between thoracic hypokyphosis, lumbar lordosis and sagittal pelvic parameters in adolescent idiopathic scoliosis. Eur. Spine J. 2013. 22. (11): 2414-2420. https://doi.org/10.1007/s00586-013-2852-z

6. de Jonge T., Dubousset J.F., Illés T.: Sagittal plane correction in idiopathic scoliosis. Spine (Phila Pa 1976). 2002. 27. (7): 754760. https://doi.org/10.1097/00007632-200204010-00013

7. Deschênes S., Charron G., Beaudoin G..: Labelle radiation dose with a new slot-scanning X-ray imager. Spine (Phila Pa 1976) 2010. 35. (9): 989-994. https://doi.org/10.1097/BRS.0b013e3181bdcaa4

8. Duval-Beaupère G., Schmidt C., Cosson P.: A Barycentremetric study of the sagittal shape of spine and pelvis: the conditions required for an economic standing position. Ann. Biomed Eng. 1992. 20. (4): 451-462. https://doi.org/10.1007/BF02368136

9. Hu P., Yu M., Liu X., Zhu B., Liu Z.: Analysis of the relationship between coronal and sagittal deformities in adolescent idiopathic scoliosis. Eur. Spine J. 2016. 25. (2): 409-416. https://doi.org/10.1007/s00586-015-3986-y

10. IllésS. T.:Aderékfájás:mikorés mittegyünk?.Orv. Hetil. 2015.156.(33):1315-1320. https://doi.org/10.1556/650.2015.30232

11. Illés T., Somoskeöy S.: Az EOS ${ }^{T M}$ röntgengép elve és gyakorlati használata a mindennapi ortopédiai gyakorlatban. Orv. Hetil. 2012. 153. (8): 289-295. https://doi.org/10.1556/OH.2012.29312

12. Illés T., Somoskeöy S.: The EOS ${ }^{T M}$ imaging system and its uses in daily orthopaedic practice. Int. Orthop. 2012. 36. (7): 13251331. $\mathrm{https://doi.org/10.1007/s00264-012-1512-y}$

13. Kobayashi T., Atsuta Y., Matsuno T, Takeda N.: A longitudinal study of congruent sagittal spinal alignment in an adult cohort. Spine (Phila Pa 1976) 2004. 29. (6): 671-676. https://doi.org/10.1097/01.BRS.0000115127.51758.A2

14. Labelle H., Roussouly P., Berthonnaud E., Transfeldt E., O'Brien M., Chopin D., Hresko T., Drimnet J.: Spondylolisthesis, pelvic incidence, and spinopelvic balance: a correlation study. Spine (Phila Pa 1976). 2004. 29. (18): 2049-2054. https://doi.org/10.1097/01.brs.0000138279.53439.cc

15. Legaye J., Duval-Beaupère G., Hecquet J., Marty C.: Pelvic incidence: a fundamental pelvic parameter for three-dimensional regulation of spinal sagittal curves. Eur. Spine J. 1998. 7. (2): 99-103. https://doi.org/10.1007/s005860050038

16. Lenke L. G., Betz R. R., Harms J., Bridwell K. H., Clements D. H., Lowe T. G.. Blanke K.: Adolescent idiopathic scoliosis: a new classification to determine extent of spinal arthrodesis. J. Bone Joint Surg. Am. 2001. 83. (8): 1169-1181. https://doi.org/10.2106/00004623-200108000-00006

17. Li W. S., Li G., Chen Z.Q., Wood K. B.: Sagittal plane analysis of the spine and pelvis in adult idiopathic scoliosis. Chin. Med. J. (Engl). 2010. 123. (21): 2978-2982.

18. Lonner B. S., Auerbach J. D., Sponseller P., Rajadhyaksha A. D., Newton P. O.: Variations in pelvic and other sagittal spinal parameters as a function of race in adolescent idiopathic scoliosis. Spine (Phila Pa 1976) 2010. 35. (10): 374-377. https://doi.org/10.1097/BRS.0b013e3181bb4f96

19. Mac-Thiong J. M., Berthonnaud E., Dimar J. R., Betz R. R., Labelle H.: Sagittal alignment of the spine and pelvis during growth. Spine (Phila Pa 1976) 2004. 29. (15): 1642-1647. https://doi.org/10.1097/01.BRS.0000132312.78469.7B

20. Mac-Thiong J. M., Labelle H., Charlebois M., Huot M. P., de Guise J. A.: Sagittal plane analysis of the spine and pelvis in adolescent idiopathic scoliosis according to the coronal curve type. Spine (Phila Pa 1976). 2003. 28. (13): 1404-1409. https://doi.org/10.1097/01.BRS.0000067118.60199.D1

21. Mangione P., Gomez D., Senegas J.: Study of the course of the incidence angle during growth. Eur. Spine J. 1997. 6. (3): 163-167. https://doi.org/10.1007/BF01301430

22. Nguyen N. L., Kong C. Y., Hart R. A.: Proximal junctional kyphosis and failure-diagnosis, prevention, and treatment. Curr. Rev. Musculoskelet. Med. 2016. 9.(3): 299-308. https://doi.org/10.1007/s12178-016-9353-8

23. Obeid I., Boissière L., Yilgor C., Larrieu D., Pellisé F., Alanay A., Acaroglu E., Perez-Grueso F. J., Kleinstück F., Vital J. M., Bourghli A.; European Spine Study Group, ESSG.: Global tilt: a single parameter incorporating spinal and pelvic sagittal parameters and least affected by patient positioning. Eur. Spine J. 2016. 25. (11): 3644-3649. https://doi.org/10.1007/s00586-016-4649-3

24. Potter B. K., Lenke L. G., Kuklo T. R.: Prevention and management of iatrogenic flatback deformity. J. Bone Joint Surg. Am. 2004. 86. (8): 1793-1808. https://doi.org/10.2106/00004623-200408000-00027

25. Roussouly P., Gollogly S., Berthonnaud E., Dimnet J.: Classification of the normal variation in the sagittal alignment of the human lumbar spine and pelvis in the standing position. Spine (Phila Pa 1976). 2005. 30. (3): $346-353$. https://doi.org/10.1097/01.brs.0000152379.54463.65 
26. Schlégl Á., O'Sullivan I., Varga P., Than P., Vermes C.: Determination and correlation of lower limb anatomical parameters and bone age during skeletal growth (based on 1005 cases). J. Orthop. Res. 2016. 35. 1431-1441. https://doi.org/10.1002/jor.23390

27. Schlégl Á., Szuper K., Somoskeöy S., Than P.: Three dimensional radiological imaging of normal lower-limb alignment in children. Int. Orthop. 2015. 39. (10): 2073-2080. https://doi.org/10.1007/s00264-015-2851-2

28. Schlégl A. T., Szuper K., Somoskeöy S., Than P.: Az EOS 2D/3D System alkalmazhatóságának vizsgálata a szabad alsó végtag anatómiai és biomechanikai paramétereinek mérésére gyermekkorban. Orv. Hetil. 2014. 155. (43): 1701-1712. https://doi.ora/10.1556/OH.2014.30009

29. Stagnara P., De Mauroy J. C., Dran G., Gonon G. P., Costanzo G., Dimnet J., Pasquet A.: Reciprocal angulation of vertebral bodies in a sagittal plane: approach to references for the evaluation of kyphosis and lordosis. Spine (Phila Pa 1976). 1982. 7. (4): 335-342. https://doi.ora/10.1097/00007632-198207000-00003

30. Szuper K., Schlégl Á., Leidecker E., Vermes C., Somoskeöy S., Than P.: Three-dimensional quantitative analysis of the proximal femur and the pelvis in children and adolescents using an upright biplanar slot-scanning X-ray system. Pediatr. Radiol. 2015. 45. (3): 411-421. https://doi.org/10.1007/s00247-014-3146-2

31. Upasani V. V., Tis J., Bastrom T., Pawelek J., Marks M., Lonner B., Crawford A., Newton P. O.: Analysis of sagittal alignment in thoracic and thoracolumbar curves in adolescent idiopathic scoliosis: how do these two curve types differ? Spine (Phila Pa 1976). 2007. 32. (12): 1355-1359. https://doi.ora/10.1097/BRS.0b013e318059321d

32. Vialle R., Levassor N., Rillardon L., Templier A., Skalli W., Guigui P.: Radiographic analysis of the sagittal alignment and balance of the spine in asymptomatic subjects. J. Bone Joint Surg. Am. 2005. 87. (2): 260-267. https://doi.org/10.2106/00004623-200502000-00004

33. Winer B. J.: Statistical principles in experimental design. New York. McGraw-Hill. $1962.672 \quad p$. https://doi.org/10.1037/11774-000

\section{Dr. Burkus Máté}

Petz Aladár Megyei Oktató Kórház, Balesetsebészeti és Kézsebészeti Osztály

9023 Győr, Vasvári Pál u 2-4.

burkusmate@gmail.com 